

'Oppressed Innocence' in the Operas

Dedicated to Maria Clementina

Sobieska in Rome (1720-1730)

\title{
ANETA MARKUSZEWSKA
}

Institute of Musicology, University of Warsaw

Email: amarkuszewska@uw.edu.pl 


\section{sciendo}

Musicology Today • Vol. $17 \cdot 2020$

DOI: 10.2478/muso-2020-0001

\section{$\underline{\text { ABSTRACT }}$}

As a result of the Glorious Revolution of 1688, James II Stuart lost the throne of England, Scotland, and Ireland. He spent the last years of his life in France, in residence offered to his family and court by Louis XIV. Following his death in 1701, the title and claim to the throne of the three kingdoms was inherited by his son James III Stuart, who in 1719 married Maria Clementina Sobieska (1702-1735). James and his wife extended their patronage over one of Rome's major opera houses, the Teatro d'Alibert, at which 16 operas were dedicated to that couple in 1720-1730. Of those 8 that honoured Maria Clementina, 4 (half of them) deal with the topic of 'oppressed innocence', previously passed over by scholars studying the couple's patronage. These are: Eumene, (lib. A. Zeno, mus. N. Porpora, 1721), Adelaide, (lib. A. Salvi, mus. N. Porpora, 1723), Siroe, re di Persia, (lib. Metastasio, mus. N. Porpora, 1727), and Artaserse, (lib. Metastasio, mus. L. Vinci, 1730). This paper analyses the said operatic theme and attempts to explain why it is the dominant subject in operas dedicated to Sobieska. It also studies the political and propagandist potential which that theme could have for the Stuart cause.

Key words: Stuarts, Maria Clementina Sobieska, patronage, Rome, opera, oppressed innocence, Teatro d'Alibert

It is the misfortunes of Kings only which afford the proper subjects for tragedy ... Every calamity that befalls them, every injury that is done them, excites in the breast of the spectator ten times more compassion and resentment than he would have felt, had the same things happened to other men ${ }^{1}$.

Adam Smith in The Theory of Moral Sentiments (1759)

As a result of the Glorious Revolution of 1688, James II Stuart lost the throne of England, Scotland, and Ireland. He spent the last years of his life in France, in residence offered to his family and court by Louis XIV ${ }^{2}$. Following his death in 1701, the title and claim to the throne of the three kingdoms was inherited by his son James III Stuart. He had spent the early years of his life in France, but after the death of Louis XIV and a subsequent shift in French foreign policy, he had been forced to leave. He initially moved to Avignon but eventually settled in Italy, first in Urbino and later in Rome ${ }^{3}$. From there, the Catholic

1 A. Smith, The Theory of Moral Sentiments, $2^{\text {nd }}$ edn, London, A. Millar, and Edinburgh, A. Kincaid and J. Bell, 1761, p. 87.

2 E. Corp, A Court in Exile: The Stuarts in France, 1689-1718, Cambridge, Cambridge University Press, 2004.

3 E. Corp, The Stuarts in Italy 1719-1766. A Royal Court in Permanent Exile, Cambridge, Cambridge University Press, 2011; E. Corp (ed.) The Stuart Court in Rome. The Legacy of Exile, Aldershot, Ashgate, 2003.
In the Shadow of the Lost Crown.

'Oppressed Innocence' in the Operas Dedicated to

Maria Clementina Sobieska in Rome (1720-1730)
Stuarts made repeated but unsuccessful attempts to win back the English throne, which since 1714 had been occupied by the Hanoverian king George I ${ }^{4}$. In 1719 Stuart married Maria Clementina Sobieska (1702-1735), granddaughter of the Polish king John (Jan) III, whose family, like her husband's, had lost the throne'. As I will demonstrate later, the couple and its history was a perfect example of Smith's reflection I presented as a motto to this article.

A love for music was, apart from the royal families' misfortunes, another thing which James and Maria Clementina had in common (at least in the early stages of their marriage). In 1720 the Stuart couple became patrons of Rome's socially and politically most important theatre, the Teatro d'Alibert (also known as the Teatro delle Dame). In the years that followed, the first work of each carnival season was dedicated to James, and the second - to his wife. Altogether, 16 operas were dedicated to the Stuart couple in $1720-1730^{6}$. The political-propagandist context of this patronage, as well as the fact that the operas honouring James III and Maria Clementina demonstrate similarities on the level of their plots, was observed already in the eighteenth century, and later by modern scholars, notably by Jane $\mathrm{Clark}^{7}$ and Edward Corp ${ }^{8}$. The possible political significance of these

4 The list of James III's failed attempts at restoration includes the grandiose plan of an invasion with the support of a Spanish fleet in 1719 (Catholic Spain proved a staunch and willing ally of the Stuart cause). This plan petered out when the Spanish flotilla failed to reach the English coast because of a spell of bad weather. In 1722 the pro-Stuart faction in England mounted the so-called Atterbury Plot, but they were betrayed, with many of the conspirators arrested and executed before they could attain their objective. The most spectacular disaster for the Stuart cause was undoubtedly the Jacobite rising of 1745 , led by the son of James III and Maria Clementina, Charles Edward Stuart. The rebellion in Scotland ended in a decisive defeat of the Jacobite forces at the battle of Culloden in 1746. All these failed attempts, setbacks and defeats gradually undermined James's hope that he would one day succeed his father on the throne.

5 Following the death of John III Sobieski, an elective king, his family lost its position, influence, and privileges, which it had enjoyed under his reign. Attempts to retain the throne for his relatives eventually failed.

6 In this paper I do not discuss the two operas dedicated to the same couple at Rome's Teatro della Pace.

7 J. Clark, 'The Stuart Presence at the Opera in Rome', in: J. Clark, The Stuart Court in Rome, p. 86.

8 Corp, The Stuarts in Italy, p. 88. 


\section{S sciendo}

parallels, however, has not yet been fully explored, despite growing interest in the Stuart patronage in recent years?

This paper aims to analyse the theme of 'oppressed innocence' in the operas dedicated to Maria Clementina. The presence of this topic in works dedicated to her has so far gone unnoticed in academic research, even though wronged or oppressed innocence is a frequent theme in Baroque operas. It may concern both female and male protagonists, unjustly accused of committing some vile act (such as treason or infidelity) or an unnatural deed (e.g. murder), and were therefore deprived of their rights (for instance, to royal succession), of the throne, and submitted to hard moral tests. An analysis of the eight libretti dedicated to Maria Clementina proves that as many as four (half) of them deal with this theme. These are:

1. Eumene, lib. A. Zeno, mus. N. Porpora, 1721;

2. Adelaide, lib. A. Salvi, mus. N. Porpora, 1723;

3. Siroe, re di Persia, lib. Metastasio, mus. N. Porpora, 1727 ;

4. Artaserse, lib. Metastasio, mus. L. Vinci, $1730^{10}$;

9 A. Markuszewska, 'Queen of Italy, Mother of the Kings or Adelaide on Opera Stages: A Case Study of Adelaide (Rome 1723)', in V. Katalinič (ed.), Music Migrations in the Early Modern Age: People, Markets, Patterns and Styles, Zagreb, Hrvatsko muzikološko društvo, 2016, pp. 231-246; A. Markuszewska, "'And all this because of the weakness of your sex": The marital vicissitudes of Maria Klementyna Sobieska Stuart, wife of the Old Pretender to the English throne', in A. Bues (ed.), Frictions and Failures. Cultural Encounters in Crisis, Wiesbaden, Hassarewitz, 2017, pp. 163-177; A. Markuszewska, 'Nicola Porpora, a composer of drammi per musica dedicated to Maria Clementina Sobieska in Rome', in J.A. Chrościcki, Z. Flisowska and P. Migasiewicz (eds), I Sobieski a Roma. La famiglia reale polacca nella Città Eterna, Varsavia, Muzeum Pałacu Króla Jana III w Wilanowie, 2018, pp. 250-293; D. Blichmann, 'The Stuart Sobieska Opera Patronage in Rome: Political Propaganda in the Teatro Alibert (1720-1723)', in R. Rasch (ed.), Music and Power in the Baroque Era, Turnhout, Brepols, 2018, pp. 107-152; D. Blichmann, 'The Stuart-Sobieska opera patronage in Rome. Stylistic trends, music, singers and musicians (1720-1730)', in: D. Blichmann, Mélanges de l'École française de Rome - Italie et Méditerranée modernes et contemporaines, 2019, pp. 177-200.

10 In this article I am taking a closer look at the first three of these, since the last one, Artaserse, Pietro Metastasio's flagship work, has already been the subject of numerous analyses. I will only signal here that the theme of 'oppressed innocence' is represented in that opera by the figure of Arbace, wrongly accused of murdering the king. Betrayed and abandoned by those who were close to him, sentenced to death in a trial by his own father (the real murderer), he gives vent to his feelings in the famous aria Vò solcando un mar crudele, which ends Act I: "Infelice, in questo stato. / Sono da tutti abbandonato: / Meco sola è innocenza, / Che mi porta a naufragar" ("Unhappy in this
In the Shadow of the Lost Crown.

'Oppressed Innocence' in the Operas Dedicated to

Maria Clementina Sobieska in Rome (1720-1730)

The libretti of these operas were written by Arcadian poets associated with the reform of the Italian operatic libretto. Apart from Eumene, three of them were dedicated to the Stuarts either at their premieres or shortly afterwards. Why was the theme of 'oppressed innocence' so common in operas written for this couple, mostly in those dedicated to Sobieska, much more rarely - in those honouring her husband? What political-propagandist potential of this motif was observed and explored by the patrons and impresarios of the Teatro d'Alibert? Could it prove of use in James III's policies? How did the audience react to the operas staged at that theatre? These are important questions, since it appears that the operas dedicated to the Stuarts by the Teatro d'Alibert share a political resonance that sets them apart from works produced in the same period by the other, rival Roman theatres, the Teatro Capranica and the Teatro della Pace ${ }^{11}$.

condition, / I am abandoned by everyone. / All that's left to me is innocence, which leads me to my ruin.") For more on this topic, see the interesting paper by Mario Armellini, which convincingly demonstrates how Metastasio builds the sense of abandonment and isolation in his protagonist. Cf. M .Armellini, "'Meco sola é l'innocenza/ che mi porta a naufragar." Tradimento, abbandono e deriva degli affetti nell'Artaserse di Metastasio e Vinci', in G. Pitaressi (ed.), Leonardo Vinci e il suo tempo: Atti dei Convegni internazionali di studi, Reggio Calabria, iiriti editore, 2008, pp. 79-152.

11 The operas produced by Roman theatres during the period in question were inspired by a wide range of sources. The only ones in which I have been able to trace the theme of oppressed innocence are: L'innocenza difesa (1720), staged at the Teatro della Pace (lib. F. Silvani, mus. A. S. Fiorè), where the widow of the late emperor Giuditta is slanderously accused of betraying her husband and bearing another man's son, as well as Griselda (1721), produced at the Teatro Capranica (lib. A. Zeno, mus. A. Scarlatti). The latter libretto is very well known. Most of the libretti use historical subjects, either from the Antiquity or the Middle Ages, but some also make use of mythology (Ercole sul Termodonte, L'Oreste, 1723; Arianna e Teseo, 1729), chivalric romance ( $L$ 'isola d'Alcina, 1728), and French stage plays (Arminio, 1722). In cases where the librettists drew on historical subjects, they are usually linked to glorification of Rome and celebration of Roman virtues, as well as to expounding the role of Rome as the queen of the world ('Roma del mondo regina'). Such themes were encouraged and welcomed by the Roman Curia. This connection is evident, for instance, in the dedications of operas staged by the Teatro Capranica in 1727. L'amor generoso was dedicated to the aristocracy and the Curia, and II Cid - to the influential Cardinal Nicolò Coscia. The celebration of the 'triumphs of Latin virtù' (to use Reinhard Strohm's phrase) also served another important function; it brought increased recognition to the dedicatees and stressed their links to the history of Rome. It has to be noted, however, that the themes of usurpation and the rightful ruler's return to the throne were explored less frequently at the Teatro Capranica and Teatro della Pace than at the Teatro d'Alibert. Cf. 


\section{sciendo}

\section{$\underline{E U M E N E(1721)}$}

Eumene was the second production of the Teatro d'Alibert in the Carnival season of $1721^{12}$. On 2 February 1721 an English grand tourist named Richard Rawlinson made the following entry in his diary:

I went to the opera House of the Conte d'Aliberti where we were entertained with excellent Musick and good singing, the name of the play was Eumenes in which was more good sense, tenderness of expression and passion [emphasis by A.M.] than I have before observed in Italy and the different parts acted as well as sung to great perfection: the house was very full, and persons of the first quality were present as the Chevalier and his spouse, the Contestabile di Colonna, Princess Piombino, Orsino etc. It held us near 4 hours: the habits were also new, and Nicolini came in at the head of ... [the rest of the entry is illegible] ${ }^{13}$.

The opera's protagonist is based on a historical character; the real Eumene (Eumenes) was one of Alexander the Great's generals ${ }^{14}$. In the opera he is a paragon of all

also S. Franchi, Drammaturgia romana 1701-1750, Rome, Ediz. di Storia e Letteratura, 1997; E. Natuzzi, II Teatro Capranica dall'inaugurazione al 1881, Napoli, Edizioni scientifiche italiane, 1999; A. Alessandro, I teatri di Roma nel secolo decimosettimo, Rome, L. Pasqualucci Editore, 1888; B. M. Antolini, 'Il mondo dell'opera seria nella Roma del Settecento', in D. Bernini (ed.) Sogni e favole io fingo, Rome, Editrice Romana, 1985, pp. 6153; B.M. Antolini and T. Gialdroni, 'L'opera nei teatri pubblici a Roma nella prima metà del Settecento: fonti documentarie $e$ musicali', Roma moderna e contemporanea, no. 1, 1996, pp. 113-142.

12 The first opera of that Carnival was Artaserse, with a libretto by Francesco Silvani and music by Porpora. Cf. Franchi, Drammaturgia. Artaserse was based on Silvani's old libretto titled II tradimento traditor di se stesso, first presented at the Teatro S. Giovanni Grisostomo in Venice in 1711 with music by Antonio Lotti.

13 R. Rawlinson, GB-Ob, MS. Rawl. D. 1180. At the time, Porpora's Eumene was considered to be a finer work than Griselda, with music by the renowned Alessandro Scarlatti, which was playing at the same time in the rival Teatro Capranica. The already quoted Rawlinson wrote down in his diary: "Went this day to the Theater of Capranica, where we saw the opera of Griselda, played without any life or action, the songs sung so low as to be hardly heard, and the whole received without any extraordinary marks of satisfaction from the auditory." Incidentally, in modern musicology Scarlatti's Griselda is valued much more highly, the prevailing opinion being that it should be rated among the composer's best works. See, Cf. R. Strohm, 'A Context for Griselda: the Teatro Capranica in Rome, 1711-1724', in R. Strohm (ed.), Dramma per Musica, op. cit., p. 54.

14 C. Nepos, Lives of Eminent Commanders, Scotts Valley, CreateSpace Independent Publishing Platform, 2015; Plutarch, 'The Life of Eumenes', in Plutarch, The Parallel
In the Shadow of the Lost Crown.

'Oppressed Innocence' in the Operas Dedicated to

Maria Clementina Sobieska in Rome (1720-1730)

virtues, and a military leader whose intelligence and prowess are proverbial. Happily in love with Artemisia, who is the rightful ruler of Cappadocia, Eumene leads a military expedition in order to liberate Cappadocia on behalf of his beloved from the usurper queen Laodicea ${ }^{15}$. This version of Eumene was not the first occasion on which the character appeared on the European operatic scene ${ }^{16}$. It seems, however, that the Eumene dedicated to Maria Clementina was inspired by a Venetian production of 1697 with a libretto by Apostolo Zeno and music by Marc'Antonio Ziani ${ }^{17}$. It is important to stress that Eumene himself is not a pretender to the throne. Being the ruler of his own lands, he does not lay claim on the throne of Cappadocia, where he acts as a champion of the rightful ruler, Artemisia, and selflessly fights for her right to the throne (I,1).

From the very beginning, Eumene demonstrates formidable energy, dedication and the courage of conviction. He wants to win against the usurper. He is charismatic and confident, and sure of the passionate loyalty of his soldiers, who will follow him anywhere. Such a larger-than-life figure could not fail to win the instant respect and admiration of the audience.

Lives, vol. 8, Loeb Classical Library edition, http://penelope. uchicago.edu/Thayer/E/Roman/Texts/Plutarch/Lives/Eumenes*. html (accessed 20 April 2020).

15 Markuszewska, 'Eumene: A Case Study of an Opera Hero Migration in the Early Modern Age', in J. Guzy-Pasiak and A. Markuszewska (eds), Music Migration in the Early Modern Age Centres and Peripheries - People, Works, Styles, Paths of Dissemination and Influence, Warsaw, Liber Pro Arte, 2016, pp. 215-236.

16 The first opera recounting the story of Eumene was in all likelihood one produced in 1666 in the Teatro S. Steffano, Ferrara, with a libretto by Almerico Passarelli and music by Antonio Masini, which has regrettably not survived. See, Claudio Sartori, I libretti italiani a stampa dale origini al 1800, Cuneo, Bertola \& Locatelli, 1990, nr 9363.

17 In 1717 the historical figure of Eumene was featured by Antonio Salvi in his libretto entitled II pazzo per politica. The same opera was also staged under the alternative, eponymous title of Eumene. This version was produced in Livorno with music by Luca Antonio Predieri and in Venice with music by Tomaso Albinoni. Apart from these productions, another one was given in Munich in 1720, with music by Pietro Torri. However, judging by the number of productions Salvi's libretto of Eumene was decidedly less popular than Zeno's. Before the 1721 production, which is the focus of my article, Zeno's Eumene libretto was produced, with music by different composers, in the following operatic centres: 1700, Verona; 1706, Palermo; 1709, Venice; 1714, Reggio Emilia; 1715, Reggio Emilia; 1715, Naples; 1719, Milan; 1720, Florence. Cf. Sartori, I libretti italiani. 
But, in accordance with operatic conventions, Eumene and Artemisia's path to victory (and to a happy ending) is full of obstacles, setbacks, and sudden reversals of fortune. Among the officers accompanying Eumene on his mission is one Antigene, the commander of an elite army unit called the Argyraspides. He is Eumene's comrade and was formerly his friend, but is now secretly in love with Artemisia. His jealousy prompts him to plot Eumene's downfall. Antigene betrays Eumene, giving his plans away to Laodicea; as a result, the protagonist is captured and imprisoned. His behaviour in captivity offers further proof of his noble spirit, as he magnanimously forgives Antigene (II,4):

\begin{tabular}{|c|c|}
\hline Non cangia tempre & Eumene's heart \\
D'Eumene il cor; & cannot change its temper; \\
T'amerò sempre & I will always love you \\
Benchè infidel. & despite your betrayal. \\
Amore, e fede & I am repaying your error \\
Rendo al tuo error, & with love and fidelity \\
Quando mi chiede & when Heaven calls on me \\
Vendetta il Ciel. ${ }^{18}$ & To seek vengeance. \\
\hline
\end{tabular}

Laodicea, the usurper queen, confesses to Eumene that she loves him. Even when she threatens him with Artemisia's death, the righteous Eumene declares that he must remain steadfast $(\mathrm{II}, 14)$. He reacts in the same manner to the threat of his own execution. Imprisoned in his cell, he ponders on his situation and addresses fate directly, proudly promising to remain true to his word (III/9):

\begin{tabular}{|c|c|}
\hline $\begin{array}{c}\text { Opprimetemi pur, nemiche Stelle, } \\
\text { E tutto in mè stancate } \\
\text { L'odio Vostro, e 'l livor. Lacrime } \\
\text { vili }\end{array}$ & $\begin{array}{c}\text { Torment me, o hostile stars, } \\
\text { and let your hatred and envy } \\
\text { exhaust all that is in me. Vile } \\
\text { tears }\end{array}$ \\
\hline $\begin{array}{c}\text { Non m'usciran dal ciglio; e non } \\
\text { m'udrete }\end{array}$ & $\begin{array}{l}\text { will not flow from my eyes; you } \\
\text { will not hear me dissolve my }\end{array}$ \\
\hline Dividere in so & \\
\hline $\mathrm{C}$ & $\begin{array}{l}\text { fast and } \\
d\end{array}$ \\
\hline & against $\mathrm{c}$ \\
\hline $\begin{array}{c}\text { E sprezzerò il destino empio, e } \\
\text { rubelle. }\end{array}$ & $\begin{array}{c}\text { I will scorn the wicked and } \\
\text { wayward fate. }\end{array}$ \\
\hline $\begin{array}{l}\text { Opprimetemi pur, nemiche Stelle. } \\
\text { Mà la cara Artemisia... }\end{array}$ & $\begin{array}{l}\text { Torment me, o hostile stars, } \\
\text { but my dear Artemisia ... }\end{array}$ \\
\hline
\end{tabular}

In this scene the audience can fully appreciate the tragic dimension of Eumene's predicament. He sinks into the abyss of despair, but despite the cruelty of fate,

18 Eumene, p. 33.

19 Eumene, p. 59. he remains true to himself. The audience's conviction that Eumene's trials would be impossible to endure by an ordinary human is confirmed when Laodicea comes up with another cunning plan. She convinces Eumene that Artemisia has been betrayed by Antigene and that she, too, is now imprisoned and about to be executed. Laodicea entertains the mad hope that Eumene will agree to marry her in order to save the life of his beloved. Predictably, Eumene refuses to yield to her blackmail (III,11).

On hearing Laodicea confess her passion to Eumene, Leonato, the prince of Macedonia who has been a loyal ally of Laodicea and is in love with her, is consumed with envy. He orders his troops to attack Laodicea's soldiers and seeks to bring about Eumene's death. They confront each other in a duel, which Eumene wins. Artemisia and Eumene are at last free to enjoy their mutual love, and Artemisia is also able to assume her rightful place on the throne. Artemisia magnanimously forgives Laodicea her usurpation and thanks her for not executing Eumene, while the latter asks Laodicea to accept Leonato as her husband. The opera ends with a quartet of the four lovers: Eumene and Artemisia, Leonato and Laodicea.

As I mentioned before, Eumene is a special case among the protagonists of the operas dedicated to Maria Clementina in that the main character is not in fact the rightful ruler seeking to regain the throne, but a champion who fights for the throne on behalf of a wronged queen. This fact notwithstanding, Eumene is also a hero in his own right ${ }^{20}$. Though Eumene's moral steadfastness and fidelity to his own inner truth and to his beloved Artemisia remain unshaken, he nevertheless undergoes a transformation in the course of the story. When the opera begins, he is a proud and undefeated warrior, but in the course of the story he tastes the bitterness of defeat and betrayal. This experience makes him more human and more mature. It could be said that Eumene's misfortunes teach him to become a better and more compassionate ruler. In my opinion, the overall message of the opera supports the connection (or perhaps even the equation) between Eumene and James III in the minds of the audience. Once we accept such an identification, it becomes clear that, when the time comes, James III, like Eumene, will nobly live up to the task. Significantly, it is Eumene who sings the important last words before the finale featuring all the reconciled

20 This version of the libretto differs from the others in that Artemisia is a very passive character. However, in later Eumene librettos dating from the second half of the $18^{\text {th }}$ century, she will gain increasing agency. Cf. Markuszewska, Eumene. 
protagonists. These words, addressed to Eumene's little son (a mute figure in this opera) are as follows:

\begin{tabular}{|c|c|}
\hline Oh figlio amato & O beloved son, \\
Ti sia d'esempio il genitor, & let your father be an example \\
che al fine & for you, \\
Conservò la sua fede & since he has eventually \\
Ad onta del destino, ed è & remained faithful, \\
beato $^{21}$. & Shamed his fate, and is happy. \\
\hline
\end{tabular}

James III had already been the father of little Charles Edward for a year. Deprived of actual power, he possessed something more important in his Roman exile: faith. This can be understood literally as the Catholic faith which allowed him to count on political support in Rome, but also his confidence in the final victory, in his Jacobite followers, and his popularity in the Eternal City. Despite adverse circumstances, he retained a deep conviction that his mission would end in success. As the opera was dedicated to Maria Clementina, we see Eumene assisting Artemisia in attaining the same end; namely, regaining the throne that was due to her owing to her ancestry and love.

\section{ADELAIDE (1723)}

Porpora's next opera dedicated to Maria Clementina, Adelaide, was received with great applause. The already mentioned Richard Rawlinson praised both the libretto and the high values of the production: "went to the Theater of Aliberti, where was recited the Tragedy of Adelaide, which was well performed: the words good and sence [sic] no less" ${ }^{\prime 2}$. On 2 February 1723, the Gazzetta di Napoli printed a highly enthusiastic review:

In the evening [on Saturday] in the Teatro Capranica there was performed a new opera entitled Ercole sul Termodonte, and in the Teatro d'Alibert was staged a drama entitled Adelaide, which was received with the greatest, and universal, praise, not because it featured the familiar stage sets, but on account of the music by the celebrated maestro di cappella Signor Nicolò Porpora, a native of Naples, who has on many previous occasions given to this spiritual city [i.e. Rome] proof of his talent, complemented by a keen intellect. What caused the greatest enthusiasm among the professional musicians in attendance was the fact that among the three operas by Signor Porpora given at the Teatro d'Alibert each one is different and yet all are perfect. Almost every evening the Cavaliere di S. Giorgio appears in the theatre with his wife in order to listen to these dramas, not without great pleasure ${ }^{23}$ [emphasis by A.M.].

21 Eumene, p. 68.

22 GB-Ob, MS. Rawl. D. 1183, p. 1820.

23 "Nella sera [sabato] nel Teatro di Capranica si rappresentò la
In the passage above, the anonymous reviewer noted that the "Cavaliere di S. Giorgio and his consort" appeared in the theatre every night. These mysterious personages are none other than James III and his wife Maria Clementina ${ }^{24}$.

For this production, the Teatro d'Alibert used a libretto written in 1722 by Antonio Salvi and commissioned by the court in Munich for the wedding celebrations of Electoral Prince Charles Albert and Maria Amalia, Archduchess of Austria ${ }^{25}$. My research in the archives of the Order of Malta in Rome led me to believe that the management of the Teatro d'Alibert commissioned Ignazio de Bonis to adapt the libretto. ${ }^{26} \mathrm{I}$ also managed to ascertain that the changes introduced by de Bonis were very significant ${ }^{27}$.

Adelaide tells the story of an early medieval queen of Pavia, whose husband Lotario has been murdered by the evil prince Berengario ${ }^{28}$. The murderer has usurped the

nuova opera intitolata Ercole sul Termodonte e nel Teatro d'Alibert andò in Scena il Drama intitolato Adelaide, che ha riportato il maggiore, e l'universale applauso, non per le comparse delle Scene solite vedersi, ma per la composizione della Musica del Celebre Maestro di Cappella Signor Nicolò Porpora Napoletano, che in tutte l'occasioni ha dato in quest'Alma Città saggio della sua virtù, accompagnata da un vivace spirito. Quel cha ha reso meraviglia alli Professori in generale della Musica si è, che in trè Opere fatte dal detto Sig. Porpora nel sudetto Teatro d'Alibert in differenti tempi, le sue Co[m]posizioni sono state perfettissime, e diverse I'una dall'altra. Non tralasciandosi quasi ogni sera dal Cavaliere di S. Giorgio, e dalla di lei Sposa ... di sentire il detto Drama con somma sodisfazione." In: Thomas Griffin, Musical References in the 'Gazzetta di Napoli' 1681-1725, Berkeley, Fallen Leaf Press, 1993, p. 106.

24 The title of 'Chevalier de Saint-George' or 'Cavaliere di S. Giorgio' was used for James III very frequently in sources from the period.

25 Cf. F. Giuntini, I drammi per musica di Antonio Salvi. Aspetti della 'Riforma' del libretto nel primo Settecento, Bologna, ॥ Mulino, 1994, p. 73.

26 " [...] ad Igniatio de Bonis [...] per acomodare l'opera intitolata l'Adelaide", Rome, Biblioteca Magistrale e Archivi del Sovrano Ordine di Malta, entry CT 441, p. 38. Cf. also Markuszewska, Queen of Italy, Mother of the Kings, pp. 231-245. Reinhard Strohm, in his study of the 1723 Adelaide, assumes that the adaptation for Rome had been carried out by Salvi. Cf. R. Strohm, 'Handel and his Italian Opera Texts', in R. Strohm, Essays on Handel and Italian Opera, Cambridge, Cambridge University Press, 1985, p. 60.

\section{See, Markuszewska, Queen of Italy.}

28 For more details about the historical Queen Adelaide, cf. Odilo of Cluny, 'The Epitaph of Adelheid', in Queenship and Sanctity. The Lives of Mathilda and the Epitaph of Adelheid, transl. Sean 


\section{sciendo}

crowns of Pavia and of all Italy. In order to secure his rule, he intends to marry Adelaide to his son Idelberto. The story reports Adelaide's rejection of this disgraceful offer, her noble conduct in captivity and dignified behaviour in the face of oppression; finally - her appeal for help to Emperor Ottone, who subsequently becomes her ally and protector. With his help, Adelaide defeats her enemies and reclaims the throne. This brief summary of the libretto brings out many superficial similarities to Eumene. At the centre of the story is a young queen, whose right to the throne is defended by a youth who is also her love interest. The difference lies in the writer's approach to the material, evident already in the titles. Whereas Eumene focuses on the male protagonist, Adelaide centres on the character of the queen.

When we first see Adelaide on the stage, she is remembering her murdered husband and their marital bliss $(\mathrm{I}, 6)$ :

\begin{tabular}{|c|c|}
\hline $\begin{array}{c}\text { Soglio degl'avi miei, } \\
\text { Retaggio illustre, in cui felice } \\
\text { tempo }\end{array}$ & $\begin{array}{c}\text { O throne of my forebears, } \\
\text { illustrious heirloom, in whose } \\
\text { happy time }\end{array}$ \\
$\begin{array}{c}\text { Con Lotario sedei; } \\
\text { I sat with Lotario; }\end{array}$ \\
$\begin{array}{c}\text { T'involò nel tuo splendore } \\
\text { traditore. }\end{array}$ & $\begin{array}{c}\text { How much of your splendour } \\
\text { a traitor tarnished by killing my } \\
\text { husband. }\end{array}$ \\
Ah vendicarti io ben vorrei. ${ }^{29}$ & Oh, how much I yearn to avenge \\
\hline
\end{tabular}

In following scenes Adelaide confirms her image of a strong, self-sufficient monarch, who calls her champion to arms, and not that of a weak woman looking for a protector.

When Berengario enters Pavia, its people accept the new rulers. The usurper and his wife Matilde begin to push Adelaide to marry their son, which would legitimise the change of dynasty. The mounting pressure finds its climax in one of Porpora's most famous arias Noble onda, in which Adelaide welcomes her impending imprisonment, claiming that the harshness of prison life will be a fitting context for her constancy $(\mathrm{I}, 17)^{30}$.

Gilsdorf, Washington, Catholic University of America Press, 2004; E. Tesauro, Del Regno d'Italia sotto i barbari, Venice, Giacomo Hertz, 1680; L.A. Muratori, Annali d'Italia dal principio dell'era volgare sino all'anno 1750, vol. 13, Florence, Leonardo Marchini, 1827.

29 Adelaide, Drama per Musica / Da Rappresentarsi / Nella Sala dell'Illustriss.Sig. / Conte d'Alibert / Nel Carnevale dell'Anno 1723 / Dedicato / Alla Maestà / Di / Clementina / Regina / Della Gran Bretagna, Roma, Stamperia dei Bernabò, 1723, p. 14.

$30 \mathrm{I}$ analysed this aria in more detil in my paper 'Nicola Porpora,
In the Shadow of the Lost Crown.

'Oppressed Innocence' in the Operas Dedicated to

Maria Clementina Sobieska in Rome (1720-1730)

The climax of Act II comes with the scenes in the tower, where Adelaide is imprisoned (II, 7-11). She is desperately unhappy and sees death as the only hope for deliverance. Her emotional outpouring ends with an aria entitled Quanto bello agl'occhi miei, which can be described as an appeal to death. But even in the face of death and at the bottom of despair, Adelaide is still strong. Soon after, she receives a darkly apposite gift from her jailer, Matilde, who brings her two covered dishes. One contains a dagger and a flask of poison, and the other - a crown and sceptre. Adelaide chooses the dagger. As she is poised to stab herself, a horrified Idelberto threatens his mother that if Adelaide kills herself, he too will commit suicide. Matilde relents, but she is full of disdain for her son. She rages in impotent fury against Adelaide's pride, but is powerless in the face of such steadfastness. Adelaide then joins in a duet with Idelberto titled Vanne, soffril Vado e soffro $(\mathrm{II}, 12)$, where each of them sings about his or her own constancy in the face of cruel fate.

At the beginning of act III Berengario and Matilde force Adelaide to write a letter to Ottone asking him to sign a declaration of peace with Berengario on very favourable terms. But their threats are once again rendered ineffective because Adelaide's honour forbids her to write to the emperor while imprisoned by his enemies and treated as a mere slave. These are very strong words, which leave us in no doubt as to Adelaide's genuinely royal character."

\begin{tabular}{|c|c|}
\hline & \multirow[b]{2}{*}{$\begin{array}{c}\text { An unhappy slave, } \\
\text { still in your chains, neither can } \\
\text { nor should }\end{array}$} \\
\hline \multirow{2}{*}{$\begin{array}{l}\text { Una schiava infelice, } \\
\text { E ne' tuoi ceppi ancor, non può, } \\
\text { nè deve }\end{array}$} & \\
\hline & write to a monarch. \\
\hline $\begin{array}{l}\text { Scrivere ad un Monarca. } \\
\text { Rendimi di Reina }\end{array}$ & $\begin{array}{c}\text { Give me back my royal rank and } \\
\text { regalia; }\end{array}$ \\
\hline $\begin{array}{c}\text { L'Insegne, e il grado; e scriverò } \\
\text { dal Soglio. }\end{array}$ & $\begin{array}{c}\text { and I will then write from my } \\
\text { throne. }\end{array}$ \\
\hline E dirò: così chiedo, cosi voglio ${ }^{31}$. & $\begin{array}{c}\text { And I will say: it is my command } \\
\text { and wish. }\end{array}$ \\
\hline
\end{tabular}

Predictably, in this opera as well the good finally triumphs over evil, justice is served, and loyalty, honour, courage and steadfastness receive their due reward. When Ottone's armies breach the walls of Pavia, Matilde, in a final act of villainy, uses Adelaide as a human shield. Ottone is forced to suspend the attack so as not to harm his beloved. In this situation the noble Idelberto offers his life in exchange for Adelaide's. Thanks to Idelberto's

a composer...', pp. 260-261.

31 Adelaide, p. 57. 
betrayal of his parents, Ottone is able to defeat Matilde, whose maternal love prevails over her cruelty and hatred of Adelaide. After Ottone's victory, Idelberto begs the newly freed Adelaide to show mercy to his mother. The newly restored queen treats her with magnanimous clemency (Magnanima Clemenza is a word play on word alluding directly to Maria Clementina ${ }^{32}$ and generous pity (Generosa pietà). Adelaide and Ottone can finally celebrate their mutual love. In the end, the character of Italia in machina (Italia Trionfante) appears on the stage, likewise praising the victorious Ottone. This allegorical licenza is unique to the Roman version of Adelaide. It does not appear in any other of the many librettos centred around Queen Adelaide of Italy ${ }^{33}$.

The key to interpreting the Roman Adelaide can in fact be found already on the first page of the libretto, in the opera's dedication, which reads: "[...] we beg Your Majesty to continue the honour that this theatre enjoys through your patronage, following which, wishing you the same outcome that Adelaide experienced after so many misfortunes, and for which the whole world sighs [emphasis by A.M.], we make a very deep bow [to you]." ${ }^{34}$

The dedication clearly indicates that the theatre's management saw parallels between the fate of Adelaide and that of Maria Clementina. Like Adelaide, Maria Clementina came from a royal family. Her grandfather, John III Sobieski, was king of Poland, and her father, Jakub Sobieski, for a long time nurtured the ambition to reclaim his father's throne. Like Adelaide, Maria Clementina was born to a life of wealth and privilege, was imprisoned for political reasons, and escaped her captors. Both 'queens' also demonstrated a considerable amount of courage in the face of adversity. Both stories seemed to have a traditional happy ending: Adelaide married Emperor Otto I, and Maria Clementina married James III Stuart, the claimant to the English throne. Both ladies were widely praised for

32 It is worth stressing that these words do not appear in the original version of Salvi's libretto, where one reads about "virtude Eroica e forte" (A. Salvi, Adelaide, Monaco, 1722, p. 71).

33 Markuszewska, Queen of Italy, pp. 242-244.

34 "Madama, Ricorre al validissimo patroncinio di V. M. Adelaide; e noi ben volontieri ve la scorgiamo con sicurezza che Ella saprà ritrovare nell'animo generoso della M.V. quella benignità, e compatimento, che già ritrovò nel core di quel gran Ré, che la difese, e che la ripose nel Soglio. Nel presentarla però, che noi facciamo, à V. M. con tutto l'ossequio la supplichiamo à continuar à questo Teatro l'onore d'esser M.V. alla quale, augurando l'istessa sorte, che ebbe, doppo tante sciagure, Adelaide, e che il Mondo tutto sospira, facciamo un profondissimo inchino." Adelaide, pp. 3-4. their beauty, intelligence, and pleasant manner, which allowed them to win friends and supporters.

In the dedication quoted above, the authors declare their wish that Maria Clementina's fate should be similar to that of Adelaide. The audience at the Teatro d'Alibert and the readers of the printed libretto undoubtedly understood the allusion: it meant that Maria Clementina was destined to become a queen. She would not be the queen of Poland (although it should be noted that Jakub Sobieski unsuccessfully tried to persuade his son-in-law to stand as a candidate for Poland's elective throne). The authors of the dedication were in fact implying that one day Maria Clementina would sit on the throne of Great Britain. To my mind, this suggests that Adelaide's last aria, in which she praises Ottone's virtues, and the final appearance of Italia Trionfante, who addresses the emperor using the words "Viva, viva, il sublime Vincitore", should be read as allusions to Maria Clementina's husband and his political prospects.

\section{$\underline{\operatorname{SIROE}(1727)}$}

The premiere of Siroe, re di Persia, to a libretto by Pietro Metastasio, took place on 11 February $1727^{35}$. The Roman chronicler Francesco Valesio noted in his Diario di Roma: "This evening saw the premiere of the second drama in the Teatro Ariberti [sic - A.M.], which gave complete satisfaction in respect of set designs, especially in the last scene, which shows a great colonnade." 36

Siroe, re di Persia could be described as a domestic drama. The story deals with the complications that result from the king of Persia's decision to pass his crown on not to his eldest son Siroe (a paragon of virtue, loved by the soldiers and the common people alike), but to Medarse, his favourite younger son. In contrast to the heroic Siroe,

35 The original libretto set to music by Vinci was premiered in Venice in 1726, and adapted for Naples and Rome in the following year, with 8 arias exchanged. Cf. Rosy Candiani, Pietro Metastasio da poeta di teatro a 'virtuoso di poeta', Roma, Aracne, 1998, pp.191-201.

36 "Questa sera si diede incominciamento al secondo dramma nel teatro Ariberti e riesce di tutta sodisfazione nelle scene, particolarmente nell'ultima, che rappresenta un gran colonnato", in F. Valesio, G. Scano and G. Graglia (eds), Diario di Roma, vol. 4, Milano, Longanesi, 1977-1978, p. 776. Interestingly, this opera must have been of particular interest to nuns from the convent in Campo Marzio, who wrote a special request to their Cardinal Vicar, asking his permission to invite the Teatro d'Aliberti troupe to the convent so that they could listen to some arias from the opera. The request was readily granted. Cf. Valesio, Diario, p. 779. It is all the more regrettable that the score for a production that generated such special interest has not survived to our times. 


\section{sciendo}

Medarse is evil and deceitful. The opera recounts the conflict between the two brothers and the surrounding court intrigues, which at first turn against the virtuous Siroe. In the last act justice prevails, however, and Siroe, despite all his earlier adversities, becomes the king of Persia without compromising his honour or principles. How does this triumph of goodness and virtue come about? What twists of fate and changes of emotion does Metastasio have in stock for his protagonist?

Siroe is subjected to a series of humiliations and misfortunes which would break the will of any ordinary mortal. Already in the first scene he is bitterly betrayed by his father. The old Cosroe assembles his court in order to announce who is going to be his successor (un degno Erede). Since he plans to break the rules of succession and appoint his younger son as his heir, he makes both sons promise that they will accept his decision. This humiliates Siroe, who feels that he should be chosen as the successor, not only owing to his superior military prowess and numerous noble deeds, but simply because of the laws of nature $(\mathrm{I}, 1)$ :

\begin{tabular}{|c|c|}
\hline $\begin{array}{c}\text { Questa ingiusta dubbiezza } \\
\text { Abbastanza m’offende. E quali } \\
\text { sono } \\
\text { I vanti, onde Medarse aspiri al } \\
\text { trono! } \\
\text { Tu sai padre tu sai } \\
\text { Di quanto lo prevenne il nascer } \\
\text { mio. } \\
\text { Era avvezzo il mio cuore } \\
\text { Già gl'insulti a soffrir d'empia } \\
\text { fortuna, } \\
\text { Quando udì il genitore } \\
\text { I suoi primi vagiti entro la cuna. } \\
\text { Tu sai di quante spoglie } \\
\text { Siroe fin'ora I tuoi trionfi } \\
\text { accrebbe. } \\
\text { Sai tu quante ferrite } \\
\text { Mi costi la tua Gloria. Io sotto } \\
\text { il peso } \\
\text { Gemea della lorica in faccia a } \\
\text { morte } \\
\text { [...] } \\
\text { Sconvolgi per Medarse } \\
\text { Gli ordini di natura. Il vegga in } \\
\text { trono } \\
\text { Dettar leggi di Persia; } \\
\text { [... } \\
\text { Egli è secondo } \\
\text { il mondo }{ }^{37} \text {. } \\
\text { D’anni, e di merti, e ci conosce }\end{array}$ & $\begin{array}{l}\text { This unjust doubt is a sufficient } \\
\text { insult. } \\
\text { And what are those merits, } \\
\text { which make Medarse a better } \\
\text { heir to the throne! } \\
\text { Father, you are aware } \\
\text { that my birth precedes his. } \\
\text { My heart has grown accustomed } \\
\text { to suffering the indignities of } \\
\text { cruel fate } \\
\text { ever since my father first heard } \\
\text { his first cries in his cradle. } \\
\text { You know how many have fallen } \\
\text { by my hand } \\
\text { To increase your glory. } \\
\text { You know how many wounds I } \\
\text { suffered } \\
\text { So that you could triumph. } \\
\text { I bore the weight of my armour } \\
\text { looking death directly in the face. } \\
\text { [...] } \\
\text { You will contradict } \\
\text { the laws of nature for Medarse. } \\
\text { He will sit on the throne } \\
\text { And dictate his laws to all Persia. } \\
\text { [...] } \\
\text { He is second to me, } \\
\text { in years and merits, and the } \\
\text { world knows about it. }\end{array}$ \\
\hline
\end{tabular}

37 Siroe, Drama per Musica / Da Rappresentarsi / Nella Sala dell'Illustriss.Sig. / Conte d'Alibert / Nel Carnevale dell'Anno
In the Shadow of the Lost Crown.

'Oppressed Innocence' in the Operas Dedicated to

Maria Clementina Sobieska in Rome (1720-1730)

In the subsequent scenes Siroe is jilted by his lover Emira because he refuses to murder his father. Emira reveals that she wants Cosroe to die because he killed her own father and took her kingdom (so far, she has been living at the court under an assumed name and keeping her story secret). Emira assures Siroe that she will kill Cosroe even without his help. Siroe thus has to solve a moral dilemma, choosing between his father's life and the woman he loves. The choice is less complicated than it seems as the righteous Siroe simply cannot bring himself to commit patricide. Another complication is that Siroe becomes the object of revenge for another passionate female character, Laodice. She is unhappily in love with him, and out of spite she falsely accuses Siroe of having ravished her, and demands revenge from his father. Cosroe willingly listens to accusations against his elder son. Now Siroe writes an anonymous letter to his father, warning him of a possible assassination attempt. Learning about this, Emira breaks up with Siroe, who is then interrogated on Cosroe's orders, but, striving to protect Emira, refuses to give any details of the planned attack, and thus he himself becomes the prime suspect. The protagonist's misfortunes pile up in Metastasio's. Siroe is isolated, alienated and imprisoned. He becomes the object of hatred, anger and revenge, even from those dearest to him..$^{38}$ He himself is aware of his unparalleled plight (I, 13):

\begin{tabular}{|c|c|}
\hline Tutti reo mi volete, e reo non & $\begin{array}{c}\text { You all want to see me guilty, but } \\
\text { I am not; }\end{array}$ \\
sono & I have been accused but not \\
M'accusa, e mai condanna & sented \\
Un'empia, ed un germano, & by this cruel one, by my brother, \\
L'amico, e il genitore: & by my friend and my father. \\
Troppo fedel son'io, & I am too loyal: \\
Questo é il delitto mio, questo & This is my crime and this is my \\
l'errore ${ }^{39}$ mistake.
\end{tabular}

Siroe's misfortunes in Act I cannot fail but generate pity and terror in the hearts of the audience. His fate, cruel and unjust, makes the audience expect a reversal of fortune. The opera spectators want Siroe to try and save himself. Siroe's opponents, Medarse and especially Cosroe (represented as a terrible father and king who breaks the sacred laws of nature), are worthy of hatred and anger.

1727 / Dedicato / Alla Maestà / Di / Clementina / Regina / Della Gran Bretagna, Roma, Stamperia dei Bernabò, 1727, pp. 10-11.

38 The protagonist Arbace finds himself in a similar situation in Artaserse (1730)

39 Siroe, p. 29. 
The stage is thus set for a powerful confrontation between good and evil. This set of characters may have reminded the original audience of the situation of James III, who was barred from succession after the death of his father James II and of his two half-sisters from his father's first marriage, Maria and Anna. Pursuant to the provisions the Act of Settlement, adopted in 1701, the English crown could never fall into the hands of a Catholic. For this reason, upon Anna's death the throne did not pass on to her brother, but to a more distant cousin, Sophia Wittelsbach, the wife of the Elector of Hanover.

In Act II Siroe tries to defend his innocence but is still remarkably passive. His behaviour further increases his father's distrust, as Cosroe becomes certain that somebody is plotting against him. Siroe's silence is typical of the righteous protagonists of Metastasio's libretti, accused of crimes which they did not commit ${ }^{40}$. This is emphasised by the lines he repeats during interrogation scenes, such as "Dirti di più non deggio" ("I am not duty-bound to tell you more"), "Difendermi non posso, e reo non sono" ("I cannot explain myself, but I am not evil"), "Finche vuoi tacerò, così prometto" ("I will keep silent for so long as you wish, as I have promised"), "Parlar non posso" ("I cannot speak") and the aside "Che pena è tacer!" ("How painful it is to remain silent!"). Siroe nobly rejects the offer of help which comes from his loyal friend, General Arasse, who offers to start a rebellion against Cosroe. Act II also contains pessimistic comments on the life of the court, which the principal characters view as a place where everybody's life, including that of the ruler, can be in danger. In the words of Emira (sung in her final aria in Act II/15) the court is full of lies, betrayals and fear.

\begin{tabular}{|c|c|}
\hline $\begin{array}{l}\text { Non vi piacque ingiusti dei, } \\
\text { Ch'io nascessi pastorella; } \\
\text { Altra pena or non avrei, } \\
\text { Che la cura d'un'agnella, } \\
\text { Che l'affetto d'un pastor. } \\
\text { Ma chi nasce in regia cuna } \\
\text { Più nemica à la fortuna, } \\
\text { Che nel trono ascosi stanno. } \\
\text { E l'inganno, } \\
\text { Ed il timor }{ }^{41} \text {. }\end{array}$ & $\begin{array}{l}\text { It did not please you, O unjust } \\
\text { gods } \\
\text { for me to be born a shepherdess; } \\
\text { then I would know no other } \\
\text { suffering } \\
\text { But the care of my lambs } \\
\text { or my love for a shepherd. } \\
\text { But those who are born in a } \\
\text { royal cradle } \\
\text { suffer much more adversity, } \\
\text { because lies and fear } \\
\text { sit on the throne. }\end{array}$ \\
\hline
\end{tabular}

40 E. Sala di Felice, 'Desiderio della parola e il piacere delle lacrime nel melodramma metastasiano', in M.T. Muraro (ed.), Metastasio e il mondo musicale, Florence, Leo S. Olschki, 1986, pp. 39-97, especially pp. 52-65.

41 Siroe, p. 55.
The motif of lies plays an important role in the stories of all the principal characters and in their characterisation: Cosroe intends to deceive nature and tradition by appointing Medarse as his heir; Emira is not Cosroe's true ally but his secret enemy (as the daughter of his former adversary) and she plots to assassinate him; Laodice lies to Cosroe that Siroe ravished her; Medarse pretends that he loves his father while in fact he is motivated solely by self-interest. Furthermore, in Act III Arasse lies to Cosroe, pretending that he killed Siroe on his orders. Even when Laodice confesses the truth and admits that she lied about the rape because of her unrequited love, this does not resolve the complicated situation. On the contrary, it inspires Cosroe's jealousy, because he sees Siroe as a rival for Laodice's hand.

The most emotionally charged scenes in Act III involve Cosroe, Emira, and Arasse. The latter informs the king that Siroe is dead, and that it was his dying wish for Arasse to defend Cosroe. This message deeply moves Emira, who calls Cosroe (in quick succession) a barbarian (barbaro), a tyrant (tiranno), a monster of cruelty (mostro di crudelta), the shame of Persia (vergogna della Persia), and finally, the object of hate of the whole world (odio del mondo). No one, not even the closest ally, is allowed to insult the king, so Cosroe is staggered by her outburst. But Emira is past caring; she reveals her true identity as the daughter of Cosroe's fallen enemy and confesses that she has plotted his death. She also adds that Siroe was the one who always defended his father and stood by his side. Emira is sent to prison, and the stunned Cosroe is left with his guilty conscience and bitter knowledge.

Meanwhile, in Act III the imprisoned Siroe, accused of crimes he did not commit, succumbs to deep moral despair (III, 9):

\begin{tabular}{|c|c|}
\hline $\begin{array}{c}\text { Son stanco, ingiusti numi, } \\
\text { Di soffrir l'ira vostra. A che mi } \\
\text { giova }\end{array}$ & $\begin{array}{c}\text { O unjust gods, I am weary } \\
\text { of suffering your wrath. What } \\
\text { use to me are }\end{array}$ \\
$\begin{array}{c}\text { Innocenza, e virtù s'opprime il } \\
\text { giusto, }\end{array}$ & $\begin{array}{c}\text { innocence and virtue if the just } \\
\text { man is oppressed and the traitor } \\
\text { raised up? If human } \\
\text { merits are thus weighed up by } \\
\text { 'inalza il traditor? Se i merti } \\
\text { umani }\end{array}$ \\
$\begin{array}{c}\text { Costrea, bilancia Astrea, } \\
\text { Oregge il caso, o l'innocenza } \\
\text { è rea }{ }^{42} \text {. }\end{array}$ & $\begin{array}{c}\text { then either chance rules or } \\
\text { innocence is evil. }\end{array}$ \\
\hline
\end{tabular}

Siroe's musings are at variance with the overall Christian message of Metastasio's libretto. Human life is not ruled by chance and vice can never triumph in

42 Siroe, p.66. 


\section{sciendo}

the end. Sooner or later, all evil deeds are punished, and the wrongdoers receive their just deserts. While the final chorus contains a conventional expression of satisfaction with the happy ending, the true political and moral message of the opera is contained in the final recitative sung by Medarse (III,13):

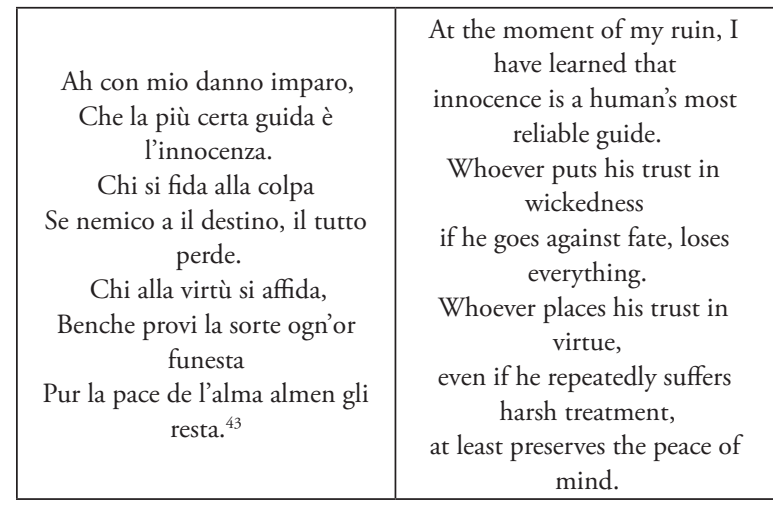

\section{CONCLUSION}

More than 20 years after the death of Maria Clementina Sobieska, the Scottish philosopher Adam Smith recognised (in the treatise which I quoted above as the motto of this paper) the universal human aspiration to reach the highest rank in a given society and to belong to the select group of the rich and powerful who shape the fate of the world. As this ambition is manifestly impossible to fulfil for the vast majority of the population, they settle for the vicarious pleasure of observing and possibly imitating the actions of those belonging to the elite (many of whom were born to privilege and spend their whole lives being observed and admired). As a consequence, becoming privy to the misfortunes of people belonging to the highest sphere of society, especially those of rulers, is apt to arouse feelings of regret and indignation in the breasts of spectators. Smith goes on to suggest that those spectators readily accept that for people of high status pain is more agonising, and suffering more acute, than for persons of lower rank $^{44}$. He asserts that the fall of a king or queen arouses in ordinary people a desire to see these monarchs restored to their rightful place. It is consistent with this undoubtedly accurate observation that during the early modern period a fundamental desire for stability and

43 Siroe, p. 70.

44 lbid., p. 76.
In the Shadow of the Lost Crown.

'Oppressed Innocence' in the Operas Dedicated to

Maria Clementina Sobieska in Rome (1720-1730)

harmony (and for their restoration in situations of crisis) would bring popularity to the theatrical topos of a ruler's downfall. In actual fact, this particular theme seems to come second in terms of frequency only to that of the two lovers who become separated and need to overcome obstacles in order to be reunited.

Smith's description of the public's reactions is highly relevant to the study of operas dedicated to Maria Clementina Sobieska (and above all to her husband James III Stuart). As a public theatre, the Teatro d'Alibert had to cater to a diverse audience. While it was still strictly hierarchical, in a sense it was also democratic. The best and most expensive seats (and boxes) in the house belonged to the richest and most powerful people in Rome - cardinals, diplomats, Italian and foreign aristocracy ${ }^{45}$. Those audience members could easily put themselves in the 'shoes' of the Stuarts; thanks to their own exalted status, they were aware of the magnitude of the Stuarts' loss and their predicament as royalty in exile. Both the supporters and enemies of the Stuarts could easily understand the political allusions hidden in the operas. The less privileged members of the audience could also in some measure share the emotions of their social betters, and they did, as Rawlison's remarks suggest. According to Smith's theory, they could experience "compassion and resentment", which were all the stronger because the operas were frequently performed in the presence of James III and his consort (whose exile, according to the Stuart propaganda, would only be temporary but in fact it lasted and offered an opportunity to feel sympathy for their fate.) The lieto fine which ended each of the operas I have analysed fulfilled the audience's "desire for stability and harmony", as mentioned by Smith. Thus, the ritual of the opera, repeated each evening during the season, was also an act of participation in an illusory political staging of Stuart restoration. Taking part in this event nobilitated the audiences in a way, inviting them to witness a historic (though imaginary) moment. Using the popular theme of 'oppressed innocence' in connection with those of the usurpation of the throne and restoration of harmony, the opera works dedicated to Maria Clementina had power

45 James and Clementina were accorded special honour by the management of the Teatro d'Alibert since they were given the right to rent as many as three boxes (a symbolical representations of the three kingdoms of England, Scotland and Ireland, and thus a subtle reminder of James's claim). No one else in that period rented so many boxes in one theatre. He also enjoyed the unique privilege of being allowed to dine in his box, and was entitled to attend rehearsals. 


\section{sciendo}

to evoke the 'appropriate emotions' ${ }^{46}$, such as sympathy, empathy, resentment, and indignation which could prove helpful to the Stuarts' political ends. It must have been felt that using the topic of 'oppressed innocence' is more suitable in works dedicated to Sobieska. It should be remembered that Maria Clementina became an oppressed innocent in her own right and a celebrity after the hair-raising escape from captivity in the fortress of Innsbruck, where she had been unlawfully imprisoned on the orders of Emperor Charles VI and King George I of England ${ }^{47}$. Oppressed innocence was thus 'her-story', to use a modern expression. It was all the more vital because James III felt that, despite papal favour and the Romans' generally positive attitude towards him, he still had continually to remind the world of the justness of his claim. It hence served his interests to link the family name to these tales of wronged rulers. Such tales found an enthusiastic audience among the opera-loving Romans who flocked to the theatre every evening during the season in order to witness the final triumph of historical or legendary monarchs on the stage, while perhaps at the same time hoping for a similar restoration of the real king who sat among them in his box.

\section{REFERENCES}

Ademollo, A., I teatri di Roma nel secolo decimosettimo, Rome, L. Pasqualucci Editore, 1888.

Antolini, B.M., 'Il mondo dell'opera seria nella Roma del Settecento', in D. Bernini (ed.), Sogni e favole io fingo, Rome, Editrice Romana, 1985, pp. 61-53.

Antolini, B.M. and T. Gialdroni, 'Lopera nei teatri pubblici a Roma nella prima metà del Settecento: fonti documentarie e musicali', Roma moderna $e$ contemporanea, no. 1, 1996, pp. 113-142.

Armellini, M., "'Meco sola é l'innocenza/che mi porta a naufragar." Tradimento, abbandono e deriva degli affetti nell'Artaserse di Metastasio e Vinci', in G. Pitaressi (ed.), Leonardo Vinci e il suo tempo: Atti dei

46 A term used by the philosopher Martha C. Nussbaum in: Political Emotions. Why Love Matters for Justice, Cambridge, Massachusetts and London, Belknap Press of Harvard University Press, 2013, p. 3.

47 The two monarchs imprisoned the young princess en route to her wedding with James III Stuart in an attempt to thwart the Stuarts. They were worried that a marriage to such a high-profile bride would boost the credibility of James's claim.
In the Shadow of the Lost Crown.

'Oppressed Innocence' in the Operas Dedicated to

Maria Clementina Sobieska in Rome (1720-1730)

Convegni internazionali di studi, Reggio Calabria: iiriti editore, 2008, pp. 79-152.

Blichmann, D., 'The Stuart - Sobieska Opera Patronage in Rome: Political Propaganda in the Teatro Alibert (1720-1723)', in R. Rasch (ed.), Music and Power in the Baroque Era, Turnhout, Brepols, 2018, pp. 107152.

Blichmann, D., 'The Stuart-Sobieska Opera Patronage in Rome. Stylistic Trends, Music, Singers and Musicians (1720-1730)', in Mélanges de l'École française de Rome - Italie et Méditerranée modernes et contemporaines, 2019, pp. 177-200.

Candiani, R., Pietro Metastasio da poeta di teatro a 'virtuoso di poeta', Roma, Aracne, 1998.

Clark, J., 'The Stuart Presence at the Opera in Rome', in The Stuart Court in Rome. The Legacy of Exile, Aldershot, Ashgate, 2003, pp. 85-93.

Corp, E. (ed.), The Stuart Court in Rome. The Legacy of Exile, Aldershot, Ashgate, 2003.

Corp, E., A Court in Exile: The Stuarts in France, 16891718, Cambridge, Cambridge University Press, 2004.

Corp, E., The Stuarts in Italy 1719-1766. A Royal Court in Permanent Exile, Cambridge, Cambridge University Press, 2011.

Franchi, S., Drammaturgia romana 1701-1750, Rome, Ediz. di Storia e Letteratura, 1997.

Giuntini, F., I drammi per musica di Antonio Salvi. Aspetti della 'Riforma' del libretto nel primo Settecento, Bologna, Il Mulino, 1994.

Griffin, Th., Musical References in the 'Gazzetta di Napoli' 1681-1725, Berkeley, Fallen Leaf Press, 1993.

Markuszewska, A., 'Eumene: A Case Study of an Opera Hero Migration in the Early Modern Age', in J. GuzyPasiak and A. Markuszewska (eds), Music Migration in the Early Modern Age Centres and Peripheries - People, Works, Styles, Paths of Dissemination and Influence, Warsaw, Liber Pro Arte, 2016a, pp. 215-236.

Markuszewska, A., 'Queen of Italy, Mother of the Kings or Adelaide on Opera Stages: A Case Study of Adelaide (Rome 1723)', in V. Katalinič (ed.), Music Migrations in the Early Modern Age: People, Markets, Patterns and Styles, Zagreb, Hrvatsko muzikološko društvo, 2016b, pp. 231-246.

Markuszewska, A., "And All This Because of 'the Weakness of Your Sex": The marital vicissitudes of Maria Klementyna Sobieska Stuart, Wife of the Old Pretender to the English Throne', in A. Bues (ed.), Frictions and Failures. Cultural Encounters in Crisis, Wiesbaden, Hassarewitz, 2017, pp. 163-177. 


\section{sciendo}

Markuszewska, A., 'Nicola Porpora, a composer of drammi per musica dedicated to Maria Clementina Sobieska in Rome', in J. A. Chrościcki, Z. Flisowska and P. Migasiewicz (eds), I Sobieski a Roma. La famiglia reale polacca nella Città Eterna, Varsavia, Muzeum Pałacu Króla Jana III w Wilanowie, 2018, pp. 250-293.

Muratori, L.A., Annali d'ttalia dal principio dell'era volgare sino all'anno 1750, vol. 13, Florence, Leonardo Marchini, 1827.

Natuzzi, E., Il Teatro Capranica dallinaugurazione al 1881, Napoli, Edizioni scientifiche italiane, 1999.

Nepos, C., Lives of Eminent Commanders, Scotts Valley, CreateSpace Independent Publishing Platform, 2015.

Nussbaum M.C., Political Emotions. Why Love Matters for Justice, Cambridge, Massachusetts and London, Belknap Press of Harvard University Press, 2013.

Odilo of Cluny, 'The Epitaph of Adelheid', in Queenship and Sanctity. The Lives of Mathilda and the Epitaph of Adelheid, transl. Sean Gilsdorf, Washington, Catholic University of America Press, 2004.

Plutarch, 'The Life of Eumenes', in Plutarch, The Parallel Lives, vol. 8, Loeb Classical Library edition, https:// penelope.uchicago.edu/Thayer/E/Roman/Texts/ Plutarch/Lives/Eumenes*.html.

Sala di Felice, E., Desiderio della parola e il piacere delle lacrime nel melodramma metastasiano, in M.T. Muraro (ed.), Metastasio e il mondo musicale, Florence, Leo S. Olschki, 1986, pp. 39-97.

Smith, A., The Theory of Moral Sentiments, $2^{\text {nd }}$ edn, A. Millar, London, and A. Kincaid and J. Bell, Edinburgh, 1761.

Strohm, R., 'Handel and his Italian Opera Texts', in R. Strohm (ed.), Essays on Handel and Italian Opera, Cambridge, Cambridge University Press, 1985.

Strohm, R., 'A Context for Griselda: The Teatro Capranica in Rome', in R. Strohm (ed.), Dramma per Musica: Italian Opera Seria of the Eighteenth Century, New Haven and London, Yale University Press, 1997, pp. 1711-1724.

Tesauro, E., Del Regno d'Italia sotto i barbari, Venice, Giacomo Hertz, 1680.

Valesio, F., G. Scano and G. Graglia (eds), Diario di Roma, vol. 4, Milano, Longanesi, 1977-1978.
In the Shadow of the Lost Crown.

'Oppressed Innocence' in the Operas Dedicated to

Maria Clementina Sobieska in Rome (1720-1730)

Aneta Markuszewska, PhD, graduated from the Institute of Musicology, University of Warsaw in 2003 on the basis of a master's thesis entitled Dramma per musica 'Tolomeo et Alessandro' by Domenico Scarlatti (supervisor: Prof. Alina Żórawska-Witkowska). In 2005 she also graduated from the Chopin Academy (now - University) of Music in Warsaw, where she had studied harpsichord with Prof. Władysław Kłosiewicz. A year later she completed her studies at the Hochschule für Musik in Würzburg in the field of Historische Tasteninstrumente (historical keyboard instruments) under the supervision of Prof. Glen Wilson. In 2011 she presented her PhD dissertation Festa i muzyka na dworze Marii Kazimiery Sobieskiej w Rzymie (1699-1714) [Festa and Music at the Court of Marie Casimire Sobieska in Rome (1699-1714)]. The book was published in Polish in 2012 and in English in 2020 and received two prizes - the Clio Award presented by the Dean and the Department of History of the University of Warsaw, and the ZKP (Polish Composers' Union) Award in the field of musicology. She has published c. 30 articles in Polish and in English. Since December 2011 she has been an Assistant Professor at the Chair of the General History of Music of the Institute of Musicology, University of Warsaw.

In the years 2012-2014 she took part in the European project ENBACH (European Network of Baroque Culture and Heritage) which received very high final assessment. In 2013-2016 she worked on the team of the HERA MusMig project (Music Migrations in the Early Modern Age: The Meeting of the European East, West and South). Since 2018, together with Gesa zur Nieden, PhD (of the Johannes Gutenberg-Universität Mainz) she has run the Polish-German project entitled Pasticcio. Ways of Arranging Attractive Operas.

Her main research interests include $17^{\text {th }}$ - and $18^{\text {th }}$-century opera, women in music and and keyboard music. 